\title{
EFFECT OF FISHMEAL REPLACEMENT WITH CHEESE PROCESSING BY-PRODUCT MEAL ON FISH PELLET QUALITY USING RING DIE PELLETING MACHINE
}

\section{M.E.I. Radwan ${ }^{1}$ and Hanan. M. El-Shal ${ }^{2}$}

\section{ABSTRACT}

This study was performed to use the cheese processing by-product meal $(C P B M)$ as an alternative source of protein instead of the expensive herring fish meal (HFM) in the practical diet of Nile tilapia fingerlings. Three feed blends containing $30 \%$ of protein were formulated with three different percentages of CPBM replacement of 0.0 (HFM=100\%), 50 and 100\% The ingredients of these blends were pelleted using a ring die pelleting machine at roller clearance of $0.0,1.5$ and $3 \mathrm{~mm}$ and different moisture contents of 15, 20 and 25\% to investigate the effect of the mentioned operating parameters on machine performance measurements, pellets quality as well as the fish growth performance. The obtained results revealed that ,CPBM percentage of $100 \%$,roller clearance of $0 \mathrm{~mm}$ and moisture content of $15 \%$ to achieve the highest values of machine productivity of $62 \mathrm{~kg} / \mathrm{h}$, pelleting efficiency of $94.50 \%$, lowest specific energy consumption of $26.70 \mathrm{~kW} . \mathrm{h} / \mathrm{Mg}$ and the lowest cost per mass unit of 2978.00 L.E/Mg, while the highest values of durability (93.50\%) and pellets bulk density $\left(940 \mathrm{~kg} / \mathrm{m}^{3}\right)$ were recorded at roller clearance of $1.5 \mathrm{~mm}$, CPBM percentage of $100 \%$ and moisture content of $15 \%$.The results showed that the complete replacement of HFM by CPBM saved the cost per mass unit with about 822 L.E/Mg. For fish growth performance, results showed that the complete replacement of CPBM fish diets gave no significant $(P>0.05)$ effect on growth performance compared to fish fed the HFM, also no disparity in growth response of fish, efficiency of feed utilization, survival rate and did not affect fish composition of dry matter, protein, or fat.So, CPBM can be used as a cheap source of protein in Nile tilapia diets instead of HFM .

Keywords: Fish meal, ring die, pellet quality, growth performance.

${ }^{1}$ Assistant professor, Central Lab. for Aquaculture Res., Agric. Res. Cent.,Egypt. ${ }^{2}$ Lecturer, Agric. Eng. Dept., Fac. of Agric., Zagazig Univ., Egypt. 


\section{INTRODUCTION}

$\mathrm{R}$ ecently, there is a new attitude of researches to use alternative protein sources from animal origin instead of herring fish meal (HFM) ,especially that the increasing demands of HFM for using in animal and fish diets resulted in the HFM becomes difficult to obtain and more expensive. Nowadays, aquaculture industry accounts for a massive $68 \%$ of global fish meal (HFM) consumption and $88 \%$ of fish oil consumption (Naylor et al., 2009). Fish meal is a major conventional ingredient in many aqua-feeds (El-Sayed, 2004); however, HFM is the single most expensive macro-feed ingredient and is highly sought after by other livestock industries (Tacon and Forster, 2000). The current developments in aquaculture feed production are seeking the substitution of HFM by alternatives which are being driven by both economic and ethical concerns such as; terrestrial plant material, rendered terrestrial animal products, krill, by-products of poultry and seafood or materials of protest origin. The use of environmental friendly protein source is desirable in modern aquaculture and one of these sources the cheese processing by-product meal (CPBM) that could alleviate the dependence on marine-derived protein and helping to decrease production costs. This by-product achieves a protein content of $34 \%$ to $89 \%$ (USDEC, 2004); that nominees it to partially or totally replace HFM in fish diets. The factors that affect pellet quality can be identified as: formulation (ingredients and moisture content), particle size, and conditioning, die specification, cooling and drying (Reimer, 1992 and behnke 2001). Fasina et al. (2004) showed that bulk density decreased and particle of pelleted litter increased by increasing the moisture content. Robohm and Apelt (1989) indicated that the maximum pellet durability exists depending upon the clearance-size between roller and die. Ultimately, as the Nile tilapia fish industry expands in Egypt, there is a need to formulate nutritious and economical diets that do not rely on HFM as a major protein source, so the aim of this study was to 
investigate the effect of replacement of herring fish meal (HFM) by cheese processing by-product meal (CPBM) in fish feed formula on machine performance, pellets quality and the fish growth performance.

\section{MATERIALS AND METHODS}

The practical experiments were carried out at feed manufacturing unit of Central Laboratory for Aquaculture Research in Abbassa, Abou Hammad district, Sharkia Governorate.

\section{A-Materials}

\section{1-Diet preparation}

Three isocaloric ingredient blends were formulated with $30 \%$ protein with energy content of $350 \mathrm{kcal} / 100 \mathrm{~g}$, as shown in Table (1-a and b).The cheese processing by-products meal centrifuged at 10,000 $\mathrm{g}$ for $15 \mathrm{~min}$ and oven dried at $55{ }^{\circ} \mathrm{C}$ for 24 hours. AOAC method (AOAC, 2003) was used to determine its proximate chemical composition as shown in Table (2). Moisture content, crude protein, crude fats, and total ash contents of CPBM were $77.1,42.2,14.3$, and $28.4 \%$, respectively.

Table (1-a): Ingredients and chemical composition of the experimental diet (on dry matter basis).

\begin{tabular}{|l|c|c|c|}
\hline \multirow{2}{*}{\multicolumn{1}{|c|}{ Ingredients }} & \multicolumn{3}{c|}{ Cheese processing by-product } \\
\cline { 2 - 4 } & $\begin{array}{c}0.0 \\
\text { (Control) }\end{array}$ & 50 & 100 \\
\cline { 2 - 4 } & D1 & D2 & D3 \\
\hline${ }^{1}$ Herring fish meal (HFM) & 10.1 & 5.1 & 0.0 \\
\hline $\begin{array}{l}\text { Cheese processing by-product } \\
\text { (CPBM) }\end{array}$ & 0.0 & 8.7 & 17.4 \\
\hline${ }^{2}$ Soybean meal & 43.1 & 43.1 & 43.1 \\
\hline Corn meal & 17.4 & 17.4 & 17.4 \\
\hline Wheat bran & 14.5 & 14.5 & 14.5 \\
\hline Cod- liver oil & 2.1 & 2.1 & 2.1 \\
\hline Corn oil & 1.8 & 1.8 & 1.8 \\
\hline${ }^{3}$ Vitamins premix & 1.0 & 1.0 & 1.0 \\
\hline${ }^{4}$ Minerals premix & 2.0 & 2.0 & 2.0 \\
\hline Starch & 8.0 & 4.3 & 0.7 \\
\hline Total & 100 & 100 & 100 \\
\hline
\end{tabular}


Table (1-b): The chemical analysis of the experimental diet.

\begin{tabular}{|l|c|c|c|}
\hline \multicolumn{1}{|c|}{ Chemical analyses (\%) } & & & \\
\hline Moisture & 7.5 & 7.6 & 7.7 \\
\hline Crude protein & 30.4 & 30.3 & 30.6 \\
\hline Ether extract & 7.4 & 7.5 & 7.4 \\
\hline Ash & 7.1 & 7.8 & 8.6 \\
\hline Crude fiber & 5.0 & 4.7 & 5.1 \\
\hline${ }^{5}$ Nitrogen-free extract & 50.1 & 49.7 & 48.3 \\
\hline${ }^{6}$ GE , (kcal/100g) & 447.1 & 445.9 & 440.9 \\
\hline P/E ratio & 68.0 & 68.0 & 69.4 \\
\hline
\end{tabular}

${ }^{1}$ Danish fish meal72\% protein, $14.2 \%$ crude fat, and $11.0 \%$ ash obtained from Triple Nine Fish Protein, DK6700 Esbjerg, Denmark.

${ }^{2}$ Egyptian soybean flour $44 \%$ protein, $1.1 \%$ crude fat, and $7.9 \%$ ash obtained from National Oil Co., Giza, Egypt.

${ }^{3}$ Vitamin premix (per kg of premix): thiamine, $2.5 \mathrm{~g}$; riboflavin, $2.5 \mathrm{~g}$; pyridoxine, $2.0 \mathrm{~g}$; inositol, $100.0 \mathrm{~g}$; biotin, $0.3 \mathrm{~g}$; pantothenic acid, $100.0 \mathrm{~g}$; folic acid, $0.75 \mathrm{~g}$; para-aminobenzoic acid, $2.5 \mathrm{~g}$; choline, $200.0 \mathrm{~g}$; nicotinic acid, $10.0 \mathrm{~g}$; cyanocobalamine, $0.005 \mathrm{~g}$; a-tocopherol acetate, $20.1 \mathrm{~g}$; menadione, $2.0 \mathrm{~g}$; retinol palmitate, $100,000 \mathrm{IU}$; cholecalciferol, 500,000 IU.

${ }^{4}$ Mineral premix (g/kg of premix): $\mathrm{CaHPO}_{4} .2 \mathrm{H}_{2} \mathrm{O}, 727.2 ; \mathrm{MgCO}_{4} .7 \mathrm{H}_{2} \mathrm{O}, 127.5 ; \mathrm{KCl} 50.0 ; \mathrm{NaCl}, 60.0$; $\mathrm{FeC}_{6} \mathrm{H}_{5} \mathrm{O}_{7} .3 \mathrm{H}_{2} \mathrm{O}, 25.0 ; \mathrm{ZnCO}_{3}, 5.5 ; \mathrm{MnCl}_{2} .4 \mathrm{H}_{2} \mathrm{O}, 2.5 ; \mathrm{Cu}(\mathrm{OAc})_{2} . \mathrm{H}_{2} \mathrm{O}, 0.785 ; \mathrm{CoCl}_{3} .6 \mathrm{H}_{2} \mathrm{O}$, $0.477 ; \mathrm{CaIO}_{3} \cdot 6 \mathrm{H}_{2} \mathrm{O}, 0.295 ; \mathrm{CrCl}_{3} \cdot 6 \mathrm{H}_{2} \mathrm{O}, 0.128 ; \mathrm{AlCl}_{3} \cdot 6 \mathrm{H}_{2} \mathrm{O}, 0.54 ; \mathrm{Na}_{2} \mathrm{SeO}_{3}, 0.03$.

${ }^{5}$ Nitrogen-free extract $=100-($ crude protein + total lipid + crude fiber + total ash $)$.

${ }^{6}$ Gross energy (GE) was calculated from ( National Research Centre,NRC, 1993) as 5.65, 9.45, and 4.1 kcal/g for protein, lipid, and carbohydrates, respectively.

Table (2): Amino acid composition of the tested diets (as \% of dietary protein) and requirements for Nile tilapia.

\begin{tabular}{|c|c|c|c|c|}
\hline \multirow{3}{*}{ Amino acids } & \multicolumn{3}{|c|}{ CPBM levels (\%) } & \multirow{3}{*}{ Requirements } \\
\hline & 0.0 (Control) & 50 & 100 & \\
\hline & D1 & D2 & D3 & \\
\hline \multicolumn{5}{|l|}{ Essential } \\
\hline Arginine & 6.25 & 5.94 & 5.21 & 4.20 \\
\hline Histidine & 3.32 & 3.33 & 3.26 & 1.72 \\
\hline Isoleucine & 4.01 & 3.96 & 3.66 & 3.11 \\
\hline Leucine & 7.23 & 7.39 & 7.18 & 3.39 \\
\hline Lysine & 6.65 & 5.52 & 4.85 & 5.12 \\
\hline Phenylalanine & 4.34 & 4.14 & 3.75 & 3.75 \\
\hline Methionine & 2.32 & 1.98 & 1.72 & 2.68 \\
\hline Threonine & 5.29 & 5.05 & 4.63 & 3.75 \\
\hline Tryptophan & 1.41 & 1.32 & 1.21 & 1.0 \\
\hline Valine & 4.44 & 4.29 & 3.85 & 2.8 \\
\hline \multicolumn{5}{|l|}{ Non-essential } \\
\hline Alanine & 4.62 & 4.29 & 4.11 & \\
\hline Aspartic acid & 9.62 & 9.41 & 8.95 & \\
\hline Cystine & 2.63 & 2.37 & 2.13 & 0.54 \\
\hline Glycine & 4.44 & 3.92 & 3.54 & \\
\hline Glutamic acid & 15.16 & 14.52 & 14.06 & \\
\hline Proline & 4.93 & 4.24 & 4.10 & \\
\hline Tyrosine & 3.61 & 3.46 & 3.24 & 1.79 \\
\hline Serine & 4.11 & 3.75 & 3.63 & \\
\hline
\end{tabular}




\section{3-The specifications of ring-die pelleting machine}

The ring-die pelleting machine was fabricated in United State of America by CPM company to produce fish feed. The pelleting machine mainly consists of the following units as illustrated in Fig. (1).

a- Feeding hopper: It was constructed of steel metal with $3 \mathrm{~mm}$ thickness, $430 \mathrm{~mm}$ length, $340 \mathrm{~mm}$ width and $450 \mathrm{~mm}$ height. The maximum capacity of feeding hopper is about $10 \mathrm{~kg}$, as shown in Fig.(1) b- Forming unit: It consists of die and roller where the clearance between the die and roller is controlled. The die has $200 \mathrm{~mm}$ in diameter, $40 \mathrm{~mm}$ in total thickness with real hole diameter of $3 \mathrm{~mm}$ and roller diameter of $90 \mathrm{~mm}$.

c- Cutting knife: It has one sharp blade so it was fixed on the ring die surface for cutting the final product to obtain the proper pellets length

d- Power unit: The main power unit including motor with rated power 2 $\mathrm{kW}$ at $1400 \mathrm{rpm}$ rotational speed, with $5.4 \mathrm{~A}$. It was used to operate the pelleting machine through reducer pulley and belt. The second motor is the conditioner motor, used to operate conditioning unit.

\section{B-Methods}

The practical experiments were performed to evaluate a ring-die pelleting machine using constant values of roller speed of $350 \mathrm{rpm}$ ( at motor speed $1400 \mathrm{rpm}$ ) and feed rate of $63 \mathrm{~kg} / \mathrm{h}$ to optimize some operating parameters affecting its performance and pellets quality using cheese processing byproduct Meal (CPBM) in fish feed formulation instead of Herring Fish Meal (HFM), these parameters are:

1- Three levels of replacement percentage of CPBM in the fish feed formula of 0 (HFM, Control), 50 and $100 \%$.

2-Three values of diet moisture content of 15,20 and $25 \%$.

3 - Three values die- roller clearance of $0,1.5$ and $3 \mathrm{~mm}$.

\section{C-Measurements}

\section{1-Machine parameters and pellets quality}

- Machine productivity

During the experiments the pellets were collected for every 30 seconds and the productivity was calculated in $\mathrm{kg} / \mathrm{h}$.

\section{-Pellets bulk density}

It was calculated using the following relationship: 


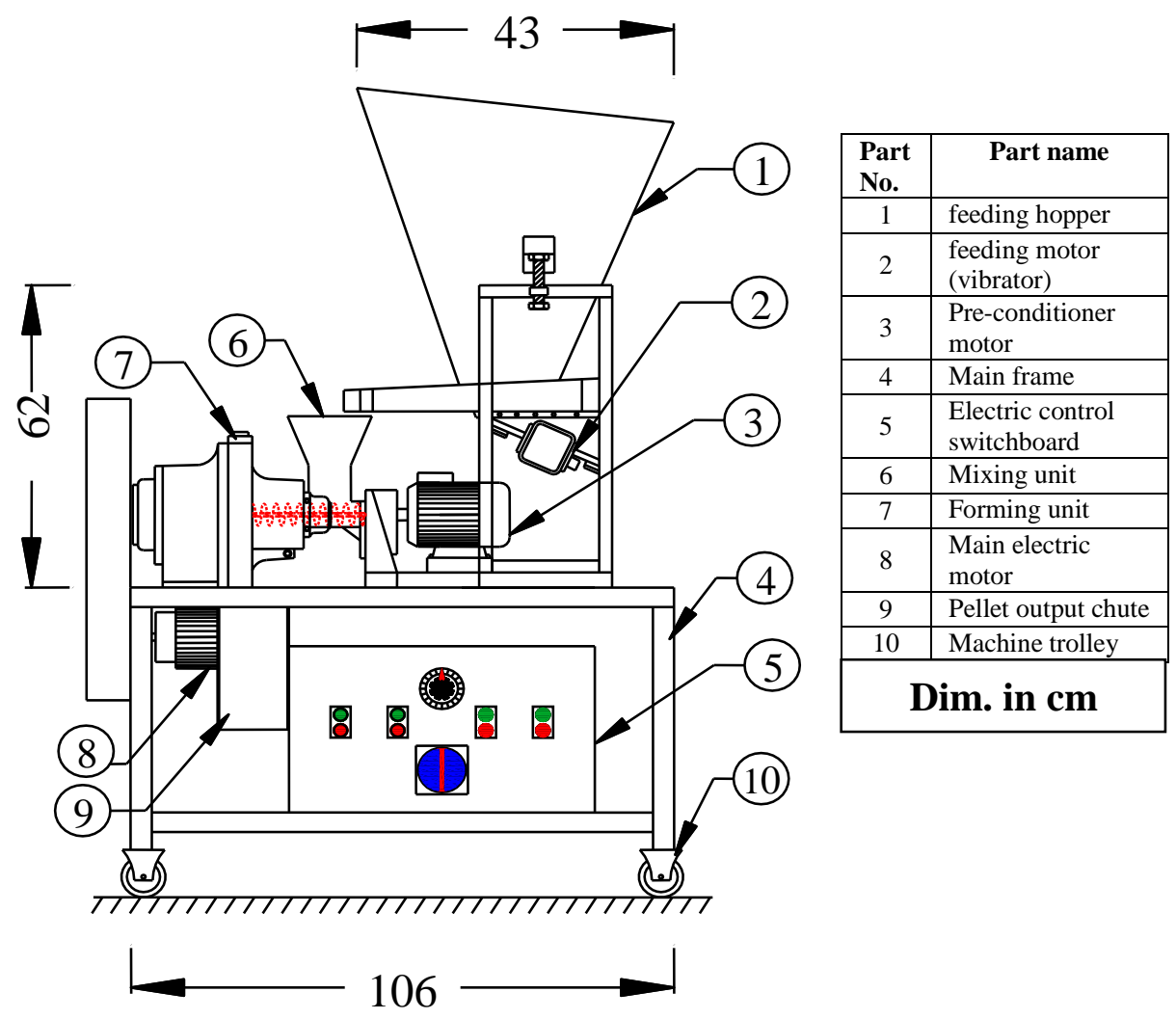

Fig. (1): The ring die pelleting machine.

Pellets bulk density $\left(\mathrm{kg} / \mathrm{m}^{3}\right)=\mathrm{W}_{\mathrm{d}} / \mathrm{V}_{\mathrm{d}}$

Where:

$\mathrm{W}_{\mathrm{d}}$ : pellets sample mass , $(\mathrm{kg})$.

$\mathrm{V}_{\mathrm{d}}$ : pellets sample volume,$\left(\mathrm{m}^{3}\right)$.

\section{-Pellet durability}

Pellet durability was determined as ASAE standards method S.269.4 DEC01 (ASAE 1996). 200 grams of the pellets were tumbled inside tumbling box device for 10 minutes and sieved through No.6 sieve and the durability was calculated as follows:

$$
\text { PDI }=\left(\frac{M_{\mathrm{at}}}{\mathrm{M}_{\mathrm{bt}}}\right) \times 100
$$

Where, PDI is the pellet durability Index (\%), $\mathrm{M}_{\mathrm{at}}$ is the mass of the pellets after tumbling $(\mathrm{g})$, and $\mathrm{M}_{\mathrm{bt}}$ is the mass of the pellets before tumbling $(\mathrm{g})$. 


\section{-The consumed power}

The consumed power, $(\mathrm{kW})=\frac{\sqrt{3} \mathrm{IV} \eta \cos \theta}{1000}$

Where:

$\mathrm{I}=$ Line current strength in amperes.

$\mathrm{V}=$ Potential difference (Voltage) being equal to $380 \mathrm{~V}$.

$\operatorname{Cos} \theta=$ Power factor (being equal to 0.84 ).

$\sqrt{3}=$ Coefficient current three phase (being equal 1.73).

$\eta=$ Mechanical efficiency assumed (90\%).

\section{-Energy requirements}

Energy requirements were obtained using the following equation:

Energy requirement $(\mathrm{kW} \cdot \mathrm{h} / \mathrm{Mg})=\frac{\text { Consumed power }(\mathrm{kW})}{\text { Machine productivity }(\mathrm{Mg} / \mathrm{h})}$

\section{2- Fish Growth performance:}

Fish growth and feed utilization were evaluated by using the following relationships:

\section{- Weight gain:}

Weight gain $=W_{2}-W_{1}$

Where :

$\mathrm{W}_{1}$ : the initial weight, $(\mathrm{g}), \mathrm{W}_{2}$ : the final weight, $(\mathrm{g})$.

\section{- Specific growth rate (SGR):}

Specific growth rate $=100\left(\ln W_{2}-\ln W_{1}\right) / T$

Where $\mathrm{W}_{1}$ and $\mathrm{W}_{2}$ are the initial and final weight, respectively, and $\mathrm{T}$ is the experimental period (days).

\section{- Feed conversion ratio:}

Feed conversion ratio $(F C R)=$ feed intake $/$ weight gain

\section{Statistical analysis}

The obtained data were analyzed by computer program of SPSS to determine the effects of levels of CPBM in fish feed formulation and its interaction with roller clearance and moisture content on machine performance as well as pellets quality. 


\section{RESULTS AND DISCUSSION}

The obtained results were discussed under the following topics:

\section{1--Effect of CPBM replacement percentage, roller clearance and} moisture content on machine productivity:

The effect of changing the levels of cheese processing by-product meal (CPBM), moisture content and roller clearance on machine productivity is illustrated in Fig.(2). The obtained results showed that, the machine productivity increased none significantly by increasing the CPBM replacement percentage from 0 to $100 \%$ so, the presence of CPBM gave values of productivity in the same range of HFM. The roller clearance had a clear effect on the productivity of the pelleting machine. This was expected because, the increase of roller clearance will decrease the compressed force for the movement in die holes that leads to low productivity. Regarding to moisture content, it's noticed that, by increasing the moisture content, the productivity decreased gradually where the increase of moisture content may cause the compressed ration to be loose and difficult to be compressed. The obtained results indicate that the highest value of machine productivity of 62 $\mathrm{kg} / \mathrm{h}$ was recorded at $\mathrm{CPBM}$ of $100 \%$, roller clearance of $0 \mathrm{~mm}$. and moisture content of $15 \%$.

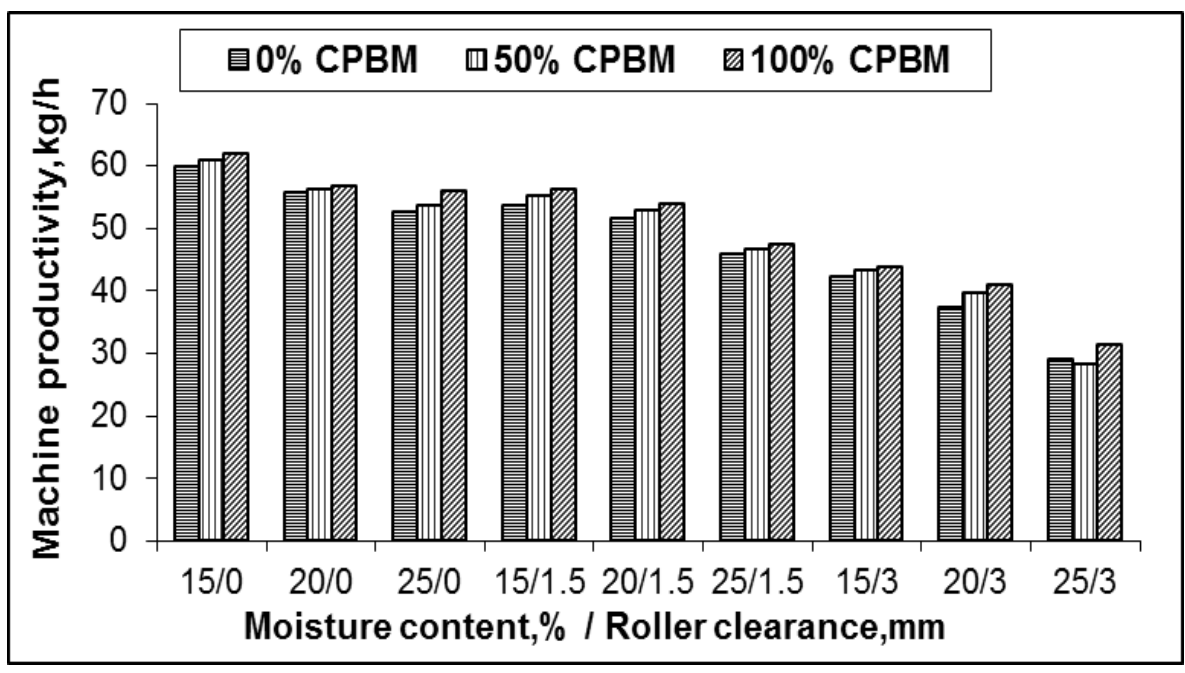

Fig.(2): Effect of the some operating parameters on machine productivity. 
2-Effect of CPBM replacement percentage, roller clearance and moisture content on pellet bulk density:

Fig.(3) depicts the effect of changing the levels of the CPBM, roller clearance and moisture content on the pellet bulk density. The obtained results showed that the pellet bulk density tends to increase.by increasing the CPBM replacement percentage from $0 \%$ to $100 \%$, This was expected because, as the percentage of CPBM decreased, the amount of starch in the feed ingredient mix increased and improved the compacting obtained in the pellet processing thus, the bulk density increased. Regarding to the roller clearance, the obtained data showed that, the bulk density increased by increasing the roller clearance from 0 to $1.5 \mathrm{~mm}$, but any further increase in the clearance up to $3 \mathrm{~mm}$, a slight reduction was occurred in the pellet bulk density. This may be due to the increase of roller clearance would increase the pressure in die holes resulting in increasing the ration compaction. Considering the moisture content, it is obvious that the increase of ration moisture content from 15 to $25 \%$ would be followed by sensible reduction in pellet bulk density. The highest pellet bulk density of $940 \mathrm{~kg} / \mathrm{m}^{3}$ was achieved at CPBM of $100 \%$, roller clearance of $1.5 \mathrm{~mm}$ and moisture content of $15 \%$.

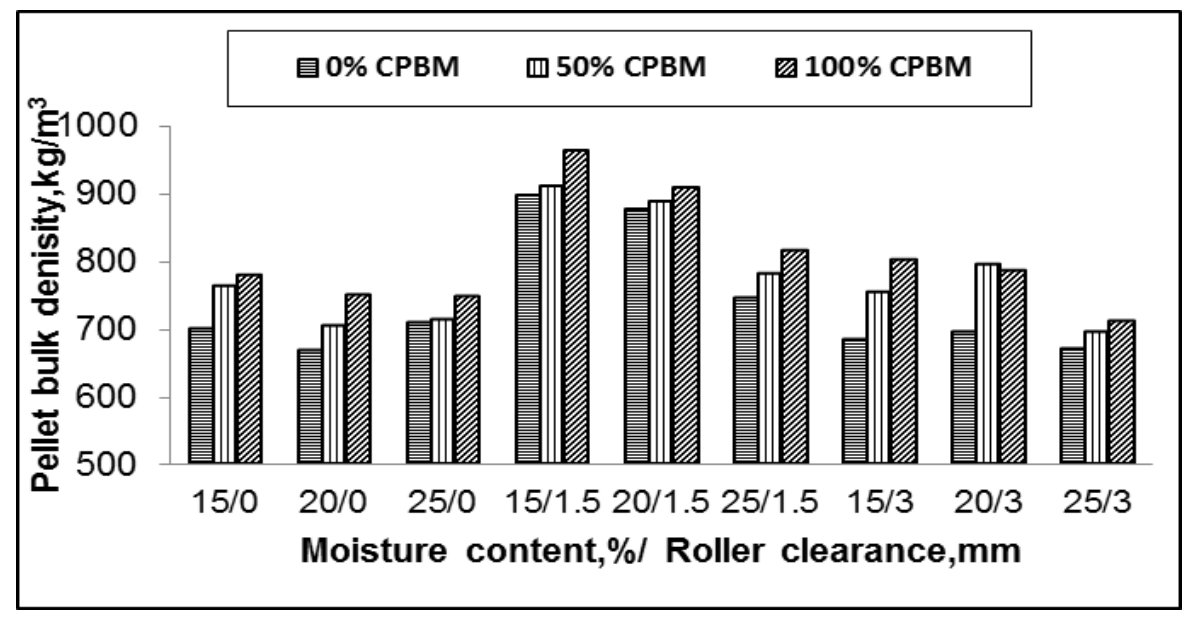

Fig.(3): Effect of the some operating parameters on pellet bulk density. 
3-Effect of CPBM replacement percentage, roller clearance and moisture content on machine pellet durability:

Pellet durability is the major aquatic feed pellets quality indicator. The effect of replacement percentage of CPBM, roller clearance and moisture content on the pellet durability is illustrated in Fig.(4). The obtained data indicated that the pellet durability increased as the CPBM replacement percentage increased from 0 to $100 \%$ in the diet. The obtained results revealed that the pellet durability increased as the roller clearance was increased from 0 to $1.5 \mathrm{~mm}$. This can be attributed to the increase of pressure inside forming unit by rising the clearance up to $1.5 \mathrm{~mm}$, that caused more compaction for the ration granules, consequently the pellet durability will increase ,but the contrarily was occurred for any increase of roller clearance more than $1.5 \mathrm{~mm}$ because the capability of roller may be reduced to compress the accumulated ration in forming unit at clearance of $3 \mathrm{~mm}$. The results showed that as the moisture content increased the pellet durability decreased The maximum pellet durability of $92.70 \%$ was achieved at CPBM of $100 \%$,roller clearance of $1.5 \mathrm{~mm}$ and moisture content of $15 \%$.

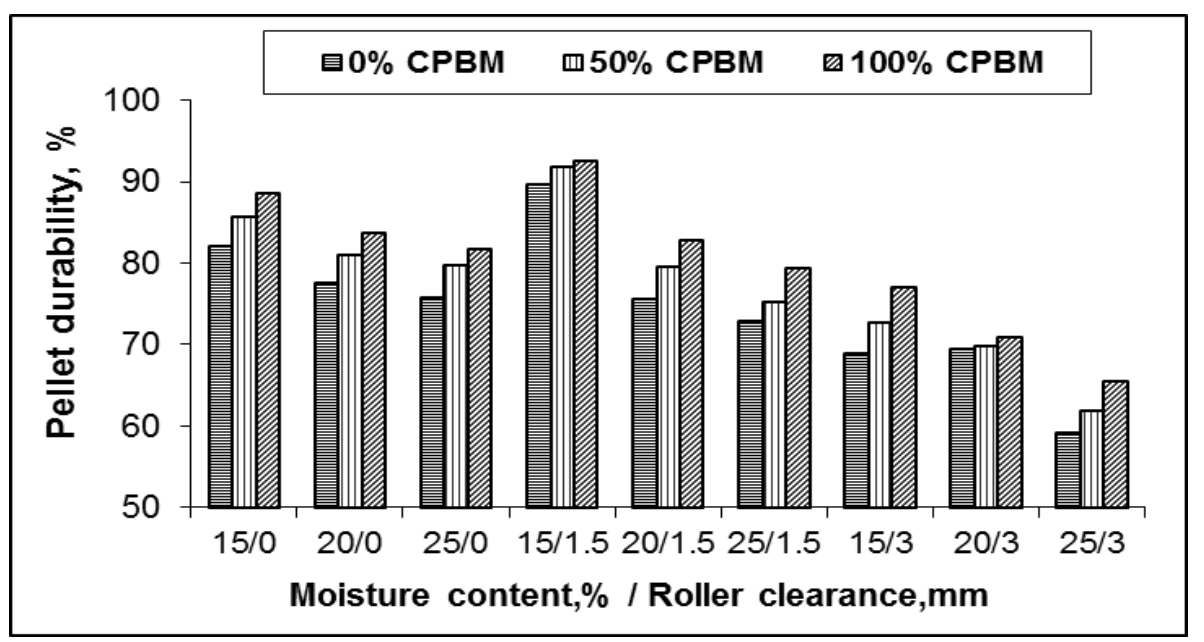

Fig.(4): Effect of the some operating parameters on pellet durability.

4-Effect of CPBM replacement percentage, roller clearance and moisture content on pelleting efficiency:

Pelleting efficiency is affected by many factors such as: formulations, clearance roller and moisture content. Considering the effect of 
changing the CPBM replacement percentage, roller clearance and moisture content on the pelleting efficiency is given in the Fig.(5). The obtained results showed that the pelleting efficiency of the compressed pellets in the ring die pelleting machine increased slightly as the CPBM increased from $0 \%$ to $100 \%$. Regarding to the effect of the moisture content on pelleting efficiency, the data showed that the pelleting efficiency decreased clearly by increasing the moisture content from $15 \%$ to $25 \%$. This decrease may due to the effect of the excessive levels of moisture content that causing a very loose pellets with high deformations and consequently a low efficiency of the pelleting process. The obtained results indicate that, as the roller clearance in ring die pellleting machine increased from 0 to $1.5 \mathrm{~mm}$, the pelleting efficiency decreased slightly but the increase of roller clearance up to $3 \mathrm{~mm}$, a clear decrease in pelleting efficiency was occurred, especially at the low levels of moisture content caused pellets deformation and decreasing the pelleting efficiency. Ultimately, the maximum pelleting efficiency of $93.50 \%$ was achieved at CPBM of $100 \%$, moisture content of $15 \%$ and roller clearance of $0 \mathrm{~mm}$, while the lowest pelleting efficiency of $60.24 \%$ was recorded at CPBM of $0 \%$, moisture content of $25 \%$ and roller clearance of $3 \mathrm{~mm}$.

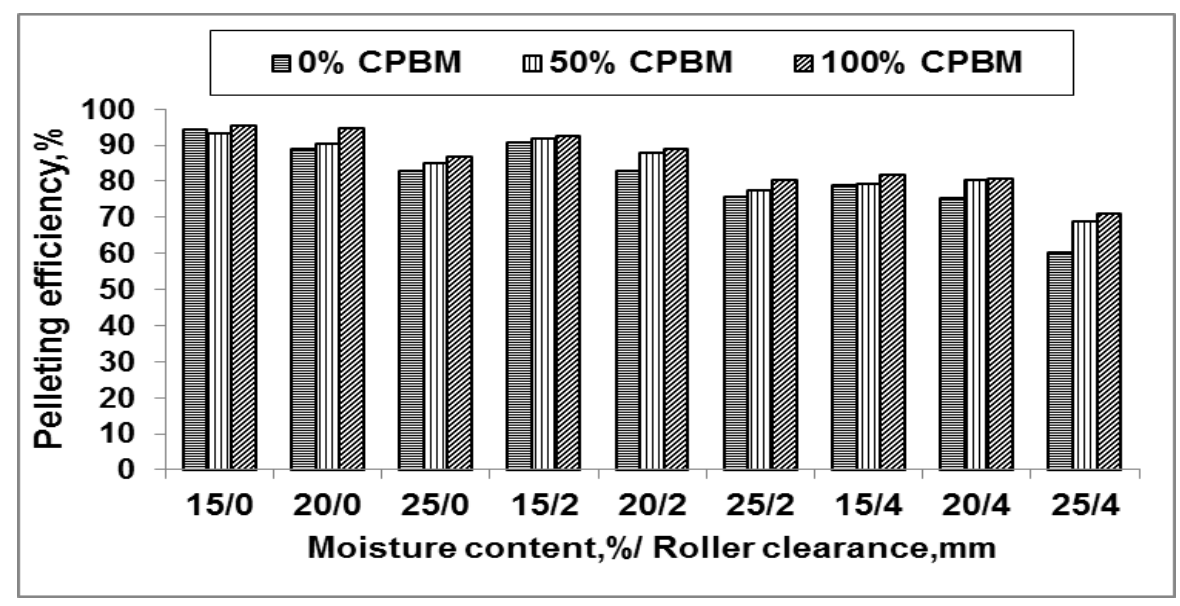

Fig.(5):Effect of the some operating parameters on pelleting efficiency. 
5-Effect of CPBM replacement percentage, roller clearance and moisture content on specific energy consumption:

Fig.(6) illustrate that, the increase of CPBM percentage from 0 to $100 \%$ caused a very low decrease in the specific energy requirements values. This is can be referred to the similar effect of both the CPBM and HFM on the machine productivity. The results showed that, as the roller clearance increased from 0 to $3 \mathrm{~mm}$, sharply decrease in specific energy requirements was occurred This can be referred to the increase the roller clearance gradually would cause a high accumulation of the ration in the gap between roller and the die with high load on the machine motor resulting in increasing of the consumed power with low productivity at the same time during pelleting process, so this is led to noticeable increase in the specific energy requirements values. Regarding to the moisture content, the specific energy consumption was drastically increased as the moisture content increased from 15 to $25 \%$. This was expected because, the sharp decrease in the machine productivity by rising up the ration moisture content, consequently the specific energy consumption. The highest specific consumption power of $92.15 \mathrm{~kW} . \mathrm{h} / \mathrm{Mg}$ was recorded at CBPM of $0 \%$, roller clearance $3 \mathrm{~mm}$ and moisture content of $25 \%$ while, the lowest specific consumption power of $26.70 \mathrm{~kW} . \mathrm{h} / \mathrm{Mg}$ was achieved at CBPM of $100 \%$, roller clearance $0 \mathrm{~mm}$ and moisture content of $15 \%$.

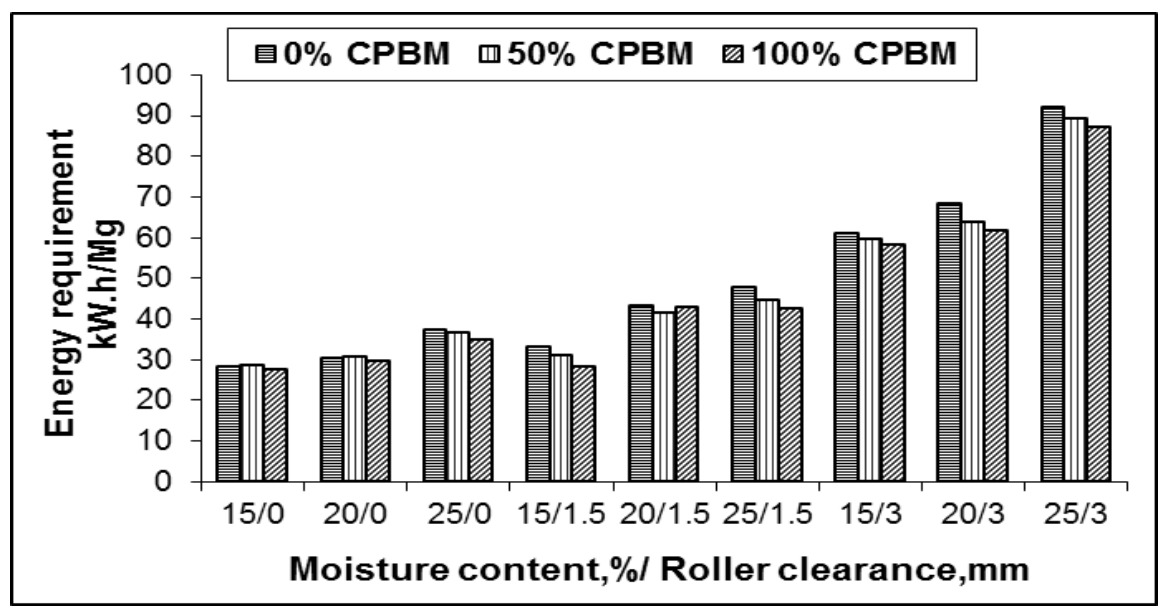

Fig.(6): Effect of the some operating parameters on the specific energy requirements . 
6-Effect of CPBM replacement percentage, roller clearance and moisture content on cost per mass unit of ring-die pelleting machine: Fig.(7).display the effect of CPBM replacement percentage on the cost per mass unit of the pelleting feeds. The obtained results indicated that the highest cost of pelleting per mass unit of $3800 \mathrm{~L} . \mathrm{E} / \mathrm{Mg}$ was recorded at $0 \% \mathrm{CPBM}$ (HFM 100\%), roller clearance of $3 \mathrm{~mm}$ and moisture content of $25 \%$, while the lowest cost per mass unit of $2978 \mathrm{~L} . \mathrm{E} / \mathrm{Mg}$ was achieved at $100 \%$ CPBM, roller clearance of $0 \mathrm{~mm}$ and moisture content of $15 \%$.So, the presence of the CPBM instead of HFM in diet decreased the pelleting cost mass per unit and saved about $822 \mathrm{LE} / \mathrm{Mg}$. could be due to the increase in machine productivity and the decrease in the price of PBM in feed formula compared to the HFM fish diets.

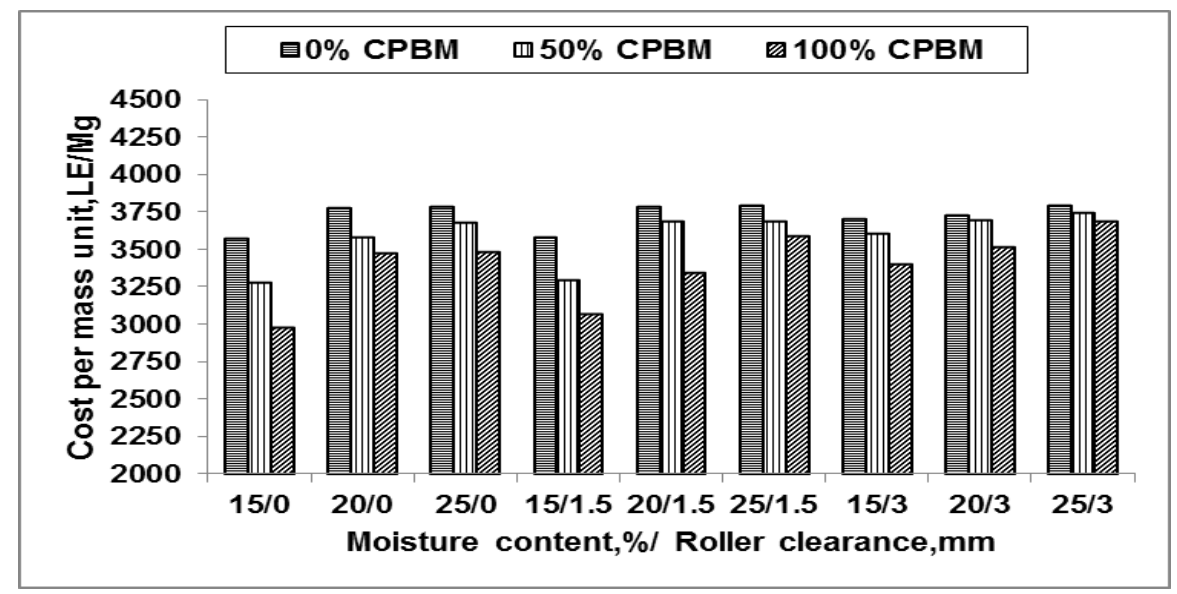

Fig.(7): Effect of the some operating parameters on cost per mass unit of ring-die pelleting machine.

\section{7- Fish growth performance:}

All Nile tilapia became accustomed to the experimental diets and were observed to feed actively during 12 weeks. Initial body weight at all experimental treatments did not differ significantly. The statistical analysis of the obtained data in Table (3) showed that growth performance (final body weight, weight gain and daily gain) and Feed efficiency (feed intake and FCR) was not significantly $(\mathrm{P}>0.05)$ differed. All diets were well accepted by Nile tilapia. Diet utilization (feed conversion ratio, FCR) was not significantly (P > 0.05) effected by 
CPBM levels. These observations suggested that the CPBM diets contained all the necessary growth factors required by Nile tilapia that explained why there was no disparity in growth response of fish and efficiency of feed utilization. Survival rate of Nile tilapia fed all the treatments was high and ranged from 96.7 to $100 \%$ without significant difference among them $(\mathrm{P}>0.05)$ as illustrated in Table (3). Feed intake increased in all groups during the experiment. Indeed, feed intake increased in all treatments during the course of the experiment, as fish grew. Feed conversion ratio showed similar values for fish fed D1 - D3; it varied between 1.35 and 1.37 as shown in Table (3).

Table (3): The growth performance for Nile tilapia fed diets containing different levels of CPBM during 12 weeks.

\begin{tabular}{|c|c|c|c|}
\hline \multirow{3}{*}{ Fish growth indicators } & \multicolumn{3}{|c|}{ CPBM levels (\%) } \\
\hline & 0.0 (Control) & 50 & 100 \\
\hline & D1 & D2 & D3 \\
\hline Initial weight,$(\mathrm{g})$ & $4.6 \pm \quad 0.06$ & $4.5 \pm \quad 0.09$ & $4.5 \pm \quad 0.06$ \\
\hline Final weight,$(\mathrm{g})$ & $31.2 \pm 0.38^{\mathrm{ab}}$ & $31.8 \pm 0.42^{\mathrm{ab}}$ & $30.5 \pm 0.61^{\mathrm{b}}$ \\
\hline Weight gain , $(\mathrm{g})$ & $26.6 \pm 0.32^{a b}$ & $27.3 \pm 0.38^{\mathrm{ab}}$ & $26.0 \pm 0.55^{\mathrm{b}}$ \\
\hline Weight gain ,\% & $738.9 \pm 3.0^{\mathrm{c}}$ & $780.0 \pm 6.5^{b}$ & $742.9 \pm 3.5^{c}$ \\
\hline Specific growth rate (SGR), $\% /$ day. & $2.53 \pm 0.004^{\mathrm{b}}$ & $2.59 \pm 0.009^{\mathrm{ab}}$ & $2.54 \pm 0.005^{\mathrm{b}}$ \\
\hline Feed Intake (FI), g feed/fish & $30.12 \pm 0.48^{\mathrm{a}}$ & $29.98 \pm 0.58^{\mathrm{a}}$ & $31.01 \pm 0.57^{\mathrm{a}}$ \\
\hline Feed conversion ratio ( FCR) & $1.35 \pm 0.04^{\mathrm{a}}$ & $1.35 \pm 0.05^{\mathrm{a}}$ & $1.37 \pm 0.05^{\mathrm{a}}$ \\
\hline Survival rate, $(\%)$ & $98.2 \pm 1.7$ & $98.2 \pm 1.7$ & $100.0 \pm \quad 0.0$ \\
\hline
\end{tabular}

-Means having the same letter in the same row is not significantly different at $P<0.05$.

\section{CONCLUSION}

From the obtained results, it is recommended to operate the ring-die pelleting machine with CPBM percentage of $100 \%$,roller clearance of 0 $\mathrm{mm}$ and moisture content of $15 \%$ to achieve the highest values of machine productivity of $62 \mathrm{~kg} / \mathrm{h}$, pelleting efficiency of $94.50 \%$, lowest specific energy consumption of $26.70 \mathrm{~kW} . \mathrm{h} / \mathrm{Mg}$ and the lowest cost per mass unit of 2978.00 L.E/Mg, while the highest values of durability $(93.50 \%)$ and pellets bulk density $\left(940 \mathrm{~kg} / \mathrm{m}^{3}\right)$ were recorded at roller clearance of $1.5 \mathrm{~mm}, \mathrm{CPBM}$ percentage of $100 \%$ and moisture content of $15 \%$.Hence, the complete replacement of HFM by CPBM with roller clearance of $0 \mathrm{~mm}$ and moisture content of $15 \%$ saved about 
822 L.E/Mg. Regarding to fish growth, results showed that no disparity in growth response of fish and efficiency of feed utilization ,Ultimately, CPBM considered a cheap source of protein in Nile tilapia diets.

\section{REFERENCES}

AOAC Association of Official Analytical Chemists ,(2003). Official Methods of Analysis of Association of Official Analytical Chemists International, $17^{\text {th }}$. Gaithersburg, Massachusetts, USA.

ASAE (1996). American society of Agricultural Engineers StandardsEngineering practices, and Data, ASAE standard book.

Behnke, K.C. (2001). Factors influencing pellet quality. Feed Tech., 5 (4): 19-22.

El-Sayed, A. F.M. (2004). Protein nutrition of farmed Tilapia: searching for unconventional sources. In: R. Bolivar, G. Mair, K. Fitzsimmons (Editors). New dimensions in farmed tilapia: proceedings of the $6^{\text {th }}$ International Symposium on Tilapia Aquaculture (2004), Manila, Philippines, 364-378 pp.

Fasina,O.O; W.Wood; F. yucheng and M. German(2004). Physical characteristics of Pellets from poultry litter. An ASAE/CSAE Annual International Meeting. Ottawa, Ontario, Canada, 1- 4 August. Paper No. 046005.

Naylor, R.L.; R.W. Hardy; D.P. Bureau; A. Chiu; M. Elliott; A.P. Farrell; I. Forster; D.M. Gatlin; R.J. Goldburg; K. Hua and P.D. Nichols (2009). Feeding aquaculture in an era of finite resources. Proceedings of the National Academy of Sciences of the United States of America, 106: 15103-15110 pp.

Reimer, L. (1992). Conditioning, In: Proc. Northern Crops Institute Feed Mill Management and Feed Manufacturing Technology,Short Course, 7. California Pellet Mill Co. Crawfordsville, IN.

Robohm, K.F. and J. Apelt (1989). Die automatische Spaltweitenverstellung. Mlhle Mischfutter., 126: 271-275.

Tacon, A.G.J. and I.P. Forster. (2000). Global trends and challenges to aquaculture and aqua-feed development in the new millennium. 
International Aqua-feed-Directory and Buyers Guide 2001, pp. 425, Turret RAI, Uxbridge, Middlesex, UK.

USDEC (2004). Products definition, composition, functions. Reference Manual for U.S. Whey and Lactose Products, 27-40 pp.

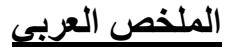

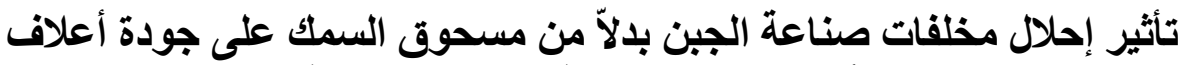

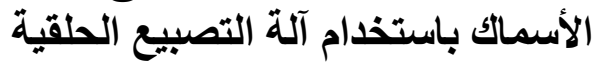 \\ حنان محمد سعدالدين الثنال؟ \\ محمد السيد إسماعيل رضوان'}

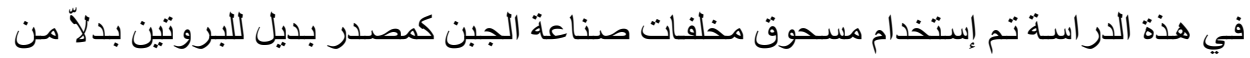

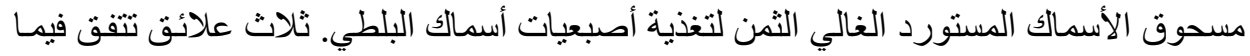

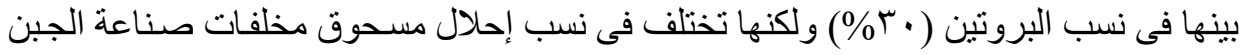

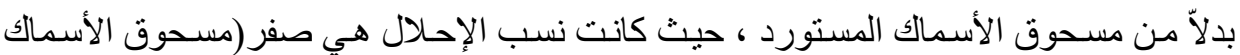

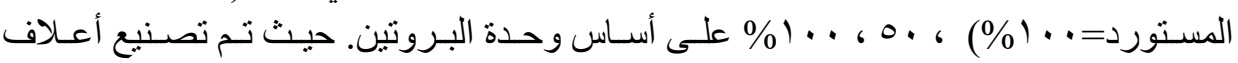

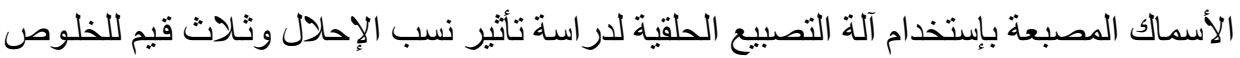

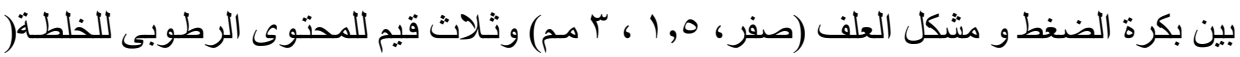

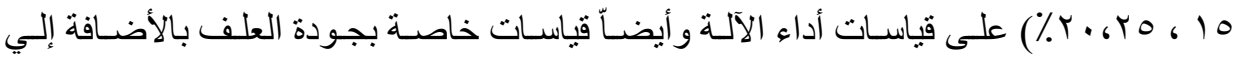

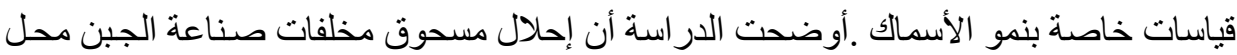

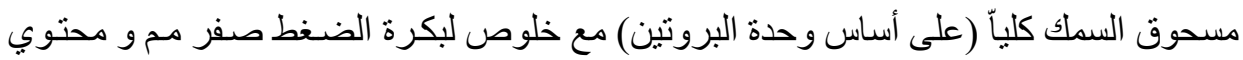

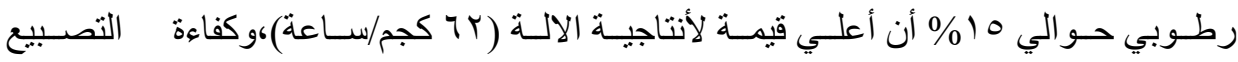

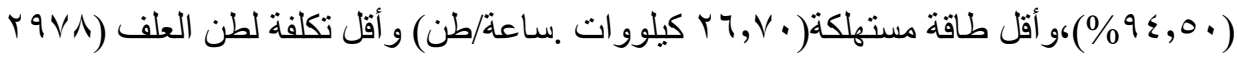

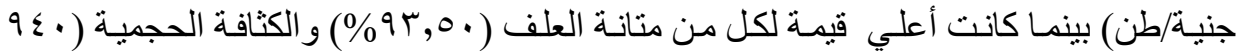

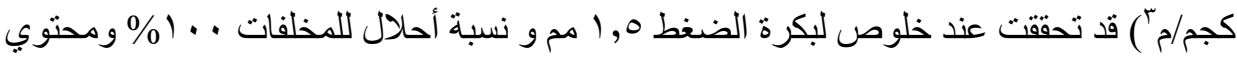

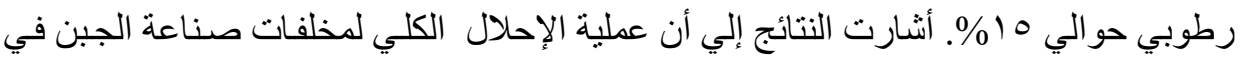

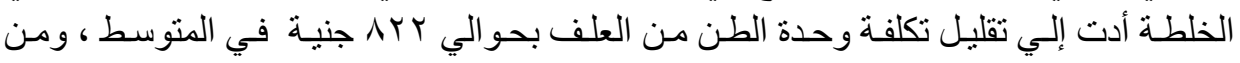

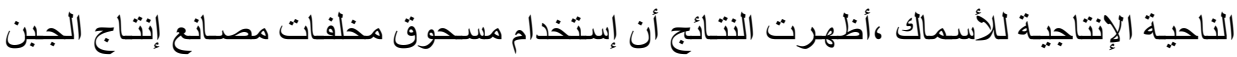

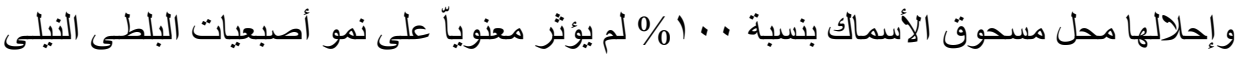

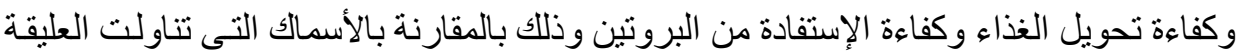

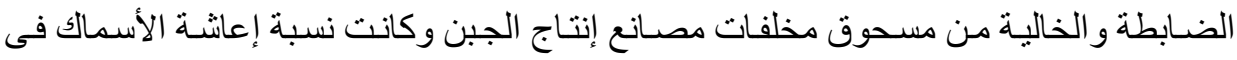

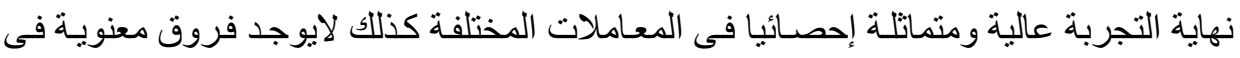

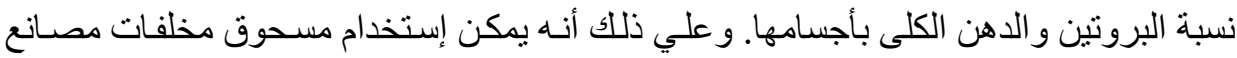

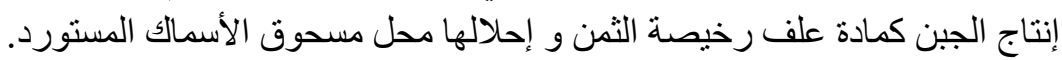

' أستاذ مساعد بالمعمل المركزى لبحوث الثروة السمكية بالعباسة ـ مركز البحوث الزراعية ـ مصر.

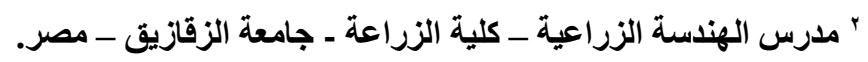

